\title{
Dimeric 1,4-Benzoquinone Derivatives with Cytotoxic Activities from the Marine-Derived Fungus Penicillium sp. L129
}

\author{
Hui-Min Zhang ${ }^{1}$, Chuan-Xia Ju ${ }^{1}$, Gang Li ${ }^{1}{ }^{\mathbb{D}}$, Yong Sun ${ }^{2}$, Yu Peng ${ }^{1}$, Ying-Xia Li ${ }^{1}$, \\ Xiao-Ping Peng ${ }^{1, *}$ and Hong-Xiang Lou ${ }^{1,2, *}$ \\ 1 Department of Natural Medicinal Chemistry and Pharmacognosy, School of Pharmacy, Qingdao University, \\ Qingdao 266021, China \\ 2 Key Laboratory of Chemical Biology of Ministry of Education, Department of Natural Product Chemistry, \\ School of Pharmaceutical Sciences, Shandong University, Jinan 250012, China \\ * Correspondence: pengxiaoping@qdu.edu.cn (X.-P.P.); louhongxiang@sdu.edu.cn (H.-X.L.); \\ Tel.: +86-150-9229-3123 (X.-P.P.); +86-531-8838-2012 (H.-X.L.)
}

Received: 12 June 2019; Accepted: 24 June 2019; Published: 26 June 2019

check for updates

\begin{abstract}
Two new dimeric 1,4-benzoquinone derivatives, peniquinone A (1) and peniquinone B (2), a new dibenzofuran penizofuran A (3), and a new pyrazinoquinazoline derivative quinadoline D (4), together with 13 known compounds (5-17), were isolated from a marine-derived fungus Penicillium sp. L129. Their structures, including absolute configurations, were elucidated by extensive spectroscopic data and electronic circular dichroism calculations. Compound 1 exhibited cytotoxicity against the MCF-7, U87 and PC3 cell lines with $\mathrm{IC}_{50}$ values of $12.39 \mu \mathrm{M}, 9.01 \mu \mathrm{M}$ and $14.59 \mu \mathrm{M}$, respectively, while compound 2 displayed relatively weak cytotoxicity activities against MCF-7, U87 and PC3 cell lines with $\mathrm{IC}_{50}$ values of $25.32 \mu \mathrm{M}, 13.45 \mu \mathrm{M}$ and $19.93 \mu \mathrm{M}$, respectively. Furthermore, compound 2 showed weak quorum sensing inhibitory activity against Chromobacterium violaceum CV026 with an MIC value of $20 \mu \mathrm{g} /$ well.
\end{abstract}

Keywords: marine-derived fungus; Penicillium sp.; secondary metabolites; quorum sensing; cytotoxicity; antifungal activity

\section{Introduction}

Marine-derived fungi are an important resource of structurally novel and unique substances. These secondary metabolites often possess diverse biological activities, enabling producers to adapt to extremely challenging environments and contributing to the complex association with other organisms in certain ecological niches [1,2]. Enthusiasm for biologically active and novel molecules has presented opportunities in the realm of marine fungi-derived secondary metabolites. A novel diketopiperazine was characterized from the mangrove-derived Penicillium brocae. It exhibited potent cytotoxicity against both sensitive and cisplatin-resistant human ovarian cancer cells and established strong antimicrobial activity against pathogenic Staphylococcus aureus [3]. Two novel lipopeptidyl benzophenones from the fungus Aspergillus sp. collected from marine-submerged decaying wood displayed significant cytotoxicity on diverse cancer cells [4]. A novel dimeric nitrophenyl trans-epoxyamide was obtained from the deep-sea-derived fungus Penicillium chrysogenum and showed an inhibitory effect on the production of the proinflammatory cytokine IL-17 [5]. Marine-derived fungi hold great potential for the discovery of new bioactive natural products (NPs).

During our search for bioactive metabolites from marine-derived fungi, Penicillium sp. L129 was isolated from the rhizosphere-soil of Limonium sinense ( Girald ) Kuntze collected in Yangkou Beach in Qingdao, China, and was rationally selected for chemical investigation after chemical 
and biological evaluation of its crude extract. Penicillium is a productive fungal genus and has been reported to produce many new NPs, such as citrinin dimer derivatives [6,7], quinazoline $[8,9]$ and indole diterpenoids [10]. Extensive chromatographic separation of the EtOAc extract of the fermented cultures resulted in the isolation of two new dimeric 1,4-benzoquinone derivatives, peniquinone $A(\mathbf{1})$ and peniquinone $B(2)$, a new dibenzofuran derivative, penizofuran $A$ (3) and a new pyrazinoquinazoline derivative quinadoline $\mathrm{D}(4)$, along with 13 known compounds, i.e., quinadoline $\mathrm{A}$ (5) [11], 3,4-dimethoxy-5-methylphenol (6) [12], orcinol (7) [13], 1,3,5,6-tetrahydroxy-8-methylxanthone (8) [14], mucorisocoumarins A (9) [15], penicillic acid (10) [16], dihydropenicillic acid (11) [16], dechlorogriseofulvin (12) [17], griseofulvin (13) [18], isogriseofulvin (14) [19], dehydrogriseofulvin (15) [20], trans-capsaicin (16) [21], and dihydrocapsaicin (17) [22] (Figure 1). Their structures were elucidated through several spectroscopic methods. Herein we report the structures and bioactivities of these compounds.

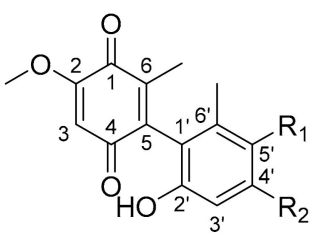

$1 \quad \mathrm{R}_{1}=\mathrm{R}_{2}=\mathrm{OCH}_{3}$

$2 \mathrm{R}_{1}=\mathrm{H} \mathrm{R} \mathrm{R}_{2}=\mathrm{OH}$<smiles>Cc1cc(O)c(O)c2oc3cc(O)cc(O)c3c(=O)c12</smiles><smiles>COC1=CC(=O)[C@@]2(Oc3c(Cl)c(OC)cc(OC)c3C2=O)C(C)C1</smiles>

14

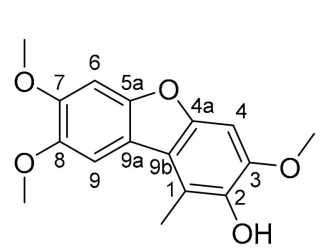

3

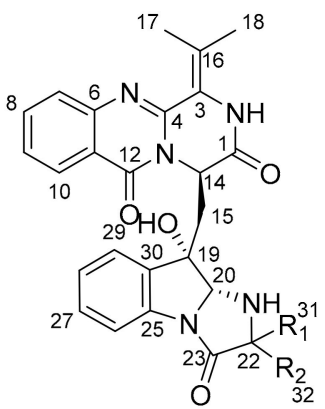

$4 \quad \mathrm{R}_{1}=\mathrm{R}_{2}=\mathrm{CH}_{2} 5 \quad \mathrm{R}_{1}=\mathrm{R}_{2}=\mathrm{CH}_{3}$<smiles>COc1cc(O)c2c(=O)oc(CC(O)CC(C)O)cc2c1</smiles>

10<smiles>[R]C(C)[C@]1(O)OC(=O)C=C1OC</smiles><smiles>[R]c1c(OC)cc(OC)c2c1O[C@]1(C(=O)C=C(OC)CC1C)[C@@H]2O</smiles><smiles>COC1=CC(=O)C=C(C)[C@]12Oc1c(Cl)c(OC)cc(OC)c1C2=O</smiles>
15<smiles>[R2]c1cc(O)cc(C)c1[R]</smiles>

$6 \quad \mathrm{R}_{1}=\mathrm{R}_{2}=\mathrm{OCH}_{3}$

$7 \quad \mathrm{R}_{1}=\mathrm{H} \mathrm{R} \mathrm{R}_{2}=\mathrm{OH}$

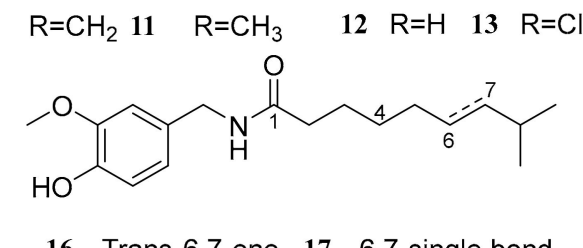

16 Trans-6,7-ene 17 6,7-single bond

Figure 1. Chemical structures of compounds 1-17.

\section{Results and Discussion}

\subsection{Structural Elucidation}

Peniquinone A (1) was obtained as a red oil. Its molecular formula was deduced as $\mathrm{C}_{17} \mathrm{H}_{18} \mathrm{O}_{6}$ with nine degrees of unsaturation according to the HRESIMS peak at $m / z 319.1171[\mathrm{M}+\mathrm{H}]^{+}$(Figure S6). Analysis of the combined 1D NMR spectral data (Table 1) established that 1 possessed two aromatic methyl groups $\left(6-\mathrm{CH}_{3}\right.$ and $\left.6^{\prime}-\mathrm{CH}_{3}\right)$, three methoxy groups $\left(2-\mathrm{OCH}_{3}, 4^{\prime}-\mathrm{OCH}_{3}\right.$ and $\left.5^{\prime}-\mathrm{OCH}_{3}\right)$, two aromatic protons (C-3 and $\left.\mathrm{C}-3^{\prime}\right)$ as well as a benzene ring. The connection mode and substitution pattern on the 1,4-benzoquinone and benzene rings were determined by key HMBC and NOSEY correlations (Figure 2). Key HMBC connections of 2- $\mathrm{OCH}_{3} / \mathrm{C}-2,4^{\prime}-\mathrm{OCH}_{3} / \mathrm{C}^{-} 4^{\prime}, 5^{\prime}-\mathrm{OCH}_{3} / \mathrm{C}^{\prime} 5^{\prime}$, $6^{\prime}-\mathrm{CH}_{3} / \mathrm{C}-1^{\prime}, 6^{\prime}-\mathrm{CH}_{3} / \mathrm{C}-5^{\prime}$, and $6^{\prime}-\mathrm{CH}_{3} / \mathrm{C}-6^{\prime}$ and the chemical shift of $\mathrm{C}-2^{\prime}$ established that the phenol fragment of compound 1 was 3,4-dimethoxy-5-methylphenol (6) [12]. The 1,4-benzoquinone ring system was also confirmed by HMBC and NOESY correlations, which was further supported by comparing its NMR data with those of reported derivatives [23,24]. Compound 1, as a new 
compound containing a dimeric 1,4-benzoquinone motif and a phenol fragment, was thus elucidated as 2'-hydroxy-2,4',5'-trimethoxy-6,6'-dimethyl-(5,1'-biphenyl)-1,4-dione.
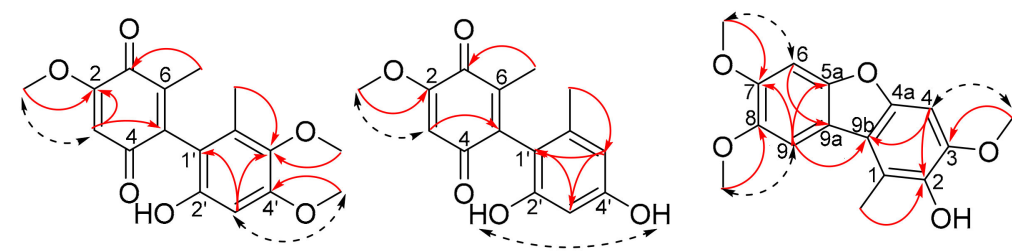

1

2

3

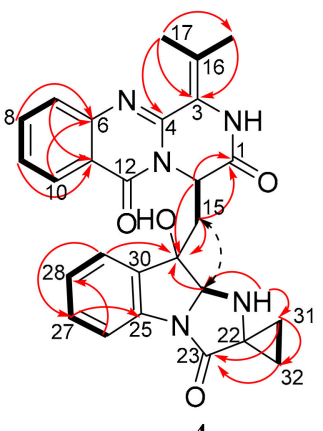

$\frown$ НмвС - COSY

4

Figure 2. The key 2D NMR correlations for compounds 1-4.

Table 1. ${ }^{1} \mathrm{H}$ and ${ }^{13} \mathrm{C}$ NMR Data for 1 and $2\left({ }^{1} \mathrm{H} 500 \mathrm{MHz},{ }^{13} \mathrm{C} 125 \mathrm{MHz}, \mathrm{TMS}, \delta \mathrm{ppm}\right)$.

\begin{tabular}{ccccc}
\hline \multirow{2}{*}{ Position } & \multicolumn{3}{c}{$\mathbf{1}^{\mathbf{a}}$} & \multicolumn{2}{c}{$2^{\mathbf{b}}$} \\
\cline { 2 - 5 } & $\delta_{\mathrm{C}}$, Type & $\delta_{\mathbf{H}}(\boldsymbol{J}$ in Hz) & $\delta_{\mathrm{C}, \text { Type }}$ & $\delta_{\mathbf{H}}(\boldsymbol{J}$ in $\mathbf{H z})$ \\
\hline 1 & $182.6, \mathrm{C}$ & & $182.3, \mathrm{C}$ & \\
2 & $158.8, \mathrm{C}$ & & $158.3, \mathrm{C}$ & \\
3 & $107.7, \mathrm{CH}$ & $6.01, \mathrm{~s}$ & $107.6, \mathrm{CH}$ & $6.11, \mathrm{~s}$ \\
4 & $186.5, \mathrm{C}$ & & $186.1, \mathrm{C}$ & \\
6 & $140.9, \mathrm{C}$ & & $141.7, \mathrm{C}$ & \\
$1^{\prime}$ & $143.0, \mathrm{C}$ & & $140.7, \mathrm{C}$ & \\
$2^{\prime}$ & $112.7, \mathrm{C}$ & & $111.7, \mathrm{C}$ & \\
$3^{\prime}$ & $148.7, \mathrm{C}$ & & $155.1, \mathrm{C}$ & \\
$4^{\prime}$ & $98.8, \mathrm{CH}$ & $6.36, \mathrm{~s}$ & $99.9, \mathrm{CH}$ & $6.16, \mathrm{~d}(1.9)$ \\
$5^{\prime}$ & $153.7, \mathrm{C}$ & & $157.9, \mathrm{C}$ & \\
$6^{\prime}$ & $141.6, \mathrm{C}$ & & $107.8, \mathrm{CH}$ & $6.13, \mathrm{~d}(1.9)$ \\
$6-\mathrm{CH}_{3}$ & $131.0, \mathrm{C}$ & & $137.3, \mathrm{C}$ & \\
$6^{\prime}-\mathrm{CH}_{3}$ & $13.6, \mathrm{CH}_{3}$ & $1.88, \mathrm{~s}$ & $13.0, \mathrm{CH}_{3}$ & $1.69, \mathrm{~s}$ \\
$2-\mathrm{OCH}_{3}$ & $13.4, \mathrm{CH}_{3}$ & $1.96, \mathrm{~s}$ & $19.5, \mathrm{CH}_{3}$ & $1.82, \mathrm{~s}$ \\
$4^{\prime}-\mathrm{OCH}_{3}$ & $56.4, \mathrm{OCH}_{3}$ & $3.85, \mathrm{~s}$ & $56.3, \mathrm{OCH}_{3}$ & $3.80, \mathrm{~s}$ \\
$5^{\prime}-\mathrm{OCH}_{3}$ & $55.8, \mathrm{OCH}_{3}$ & $3.83, \mathrm{~s}$ & & \\
$2^{\prime}-\mathrm{OH}$ & $60.6, \mathrm{OCH}_{3}$ & $3.75, \mathrm{~s}$ & & \\
$4^{\prime}-\mathrm{OH}$ & & & & $9.06, \mathrm{~s}$ \\
\hline
\end{tabular}

${ }^{\mathrm{a}}$ Recorded in $\mathrm{CDCl}_{3} ;{ }^{\mathrm{b}}$ Recorded in DMSO- $d_{6}$.

Peniquinone $\mathrm{B}$ (2) was isolated as a red oil. The molecular formula was determined to be $\mathrm{C}_{15} \mathrm{H}_{14} \mathrm{O}_{5}$ on the basis of HRESIMS $\mathrm{m} / \mathrm{z} 273.0767[\mathrm{M}-\mathrm{H}]^{-}$(Figure S14), along with the ${ }^{1} \mathrm{H}$ and ${ }^{13} \mathrm{C} \mathrm{NMR}$ data (Table 1), indicating nine degrees of unsaturation. Its 1D NMR spectra were similar to those of $\mathbf{1}$, except for an additional hydroxyl signal and an aromatic proton (Table 1, Figures S8 and S9). In addition, two aromatic proton signals exhibited a small coupling constant $(J=1.9 \mathrm{~Hz})$ (Table 1$)$. The above analysis indicated that there was resorcinol substructure in compound 2, which was further supported by HMBC correlations (Figure 2, Figures S11 and S13). Therefore, compound 2 was constructed by a 1,4-benzoquinone moiety linking with a resorcinol group. The resorcinol fragment of compound 2 was orcinol (7) [13], which was also a known structure. Thus, compound 2 was elucidated as 2', 4'-dihydroxy-2-methoxy-6,6'-dimethyl-(5,1'-biphenyl)-1,4-dione.

Penizofuran A (3) was obtained as a brown powder, and its molecular formula $\mathrm{C}_{16} \mathrm{H}_{16} \mathrm{O}_{5}$ was established from the HRESIMS $\mathrm{m} / z 289.1079[\mathrm{M}+\mathrm{H}]^{+}$(Figure S21). Nine degrees of unsaturation were indicated besides the ${ }^{1} \mathrm{H}$ and ${ }^{13} \mathrm{C}$ NMR data (Table 2). The ${ }^{1} \mathrm{H}$ NMR spectrum (Table 2) of 3 showed 
signals corresponding to one methyl (1- $\left.\mathrm{CH}_{3}\right)$, three methoxys $\left(3-\mathrm{OCH}_{3}, 7-\mathrm{OCH}_{3}\right.$ and 8- $\left.\mathrm{OCH}_{3}\right)$ and three aromatic protons (C-4, C-6 and C-9). The ${ }^{13} \mathrm{C}$ NMR spectrum showed sixteen carbon signals including twelve aromatic, one methyl, and three methoxyl groups. As two aromatic rings accounted for eight degrees of unsaturation, compound 3 was inferred to have an additional ring. Therefore, it was assumed that $\mathbf{3}$ has a dibenzofuran skeleton [25]. The position of the methyl, methoxy and hydroxyl in the dibenzofuran nucleus was established by 2D NMR data (Figure 2, Figures S19 and S20), and the key HMBC connections of $3-\mathrm{OCH}_{3} / \mathrm{C}-3,7-\mathrm{OCH}_{3} / \mathrm{C}-7,8-\mathrm{OCH}_{3} / \mathrm{C}-8,1-\mathrm{CH}_{3} / \mathrm{C}-1,1-\mathrm{CH}_{3} / \mathrm{C}-2$, and $1-\mathrm{CH}_{3} / \mathrm{C}-9 \mathrm{~b}$, and NOESY connections between $3-\mathrm{OCH}_{3}$ and $\mathrm{C}-4,7-\mathrm{OCH}_{3}$ and $\mathrm{C}-6,8-\mathrm{OCH}_{3}$ and C-9. Compound 3 , as a new compound containing the parent nucleus of dibenzofuran, was thus elucidated as 3,7,8-trimethoxy-1-methyldibenzo[b,d]furan-2-ol.

Table 2. ${ }^{1} \mathrm{H}$ and ${ }^{13} \mathrm{C}$ NMR Data for $3\left({ }^{1} \mathrm{H} 500 \mathrm{MHz},{ }^{13} \mathrm{C} 125 \mathrm{MHz}\right.$, TMS, $\delta$ ppm).

\begin{tabular}{ccc}
\hline \multirow{2}{*}{ Position } & \multicolumn{2}{c}{$3^{\mathrm{a}}$} \\
\cline { 2 - 3 } & $\delta_{\mathrm{C}, \text { Type }}$ & $\delta_{\mathbf{H}}(\boldsymbol{J}$ in Hz) \\
\hline 1 & $116.6, \mathrm{C}$ \\
2 & $140.1, \mathrm{C}$ \\
3 & $147.0, \mathrm{C}$ & \\
4 & $93.1, \mathrm{CH}$ & $7.13, \mathrm{~s}$ \\
$4 \mathrm{a}$ & $149.1, \mathrm{C}$ & \\
$5 \mathrm{a}$ & $150.3, \mathrm{C}$ & \\
6 & $96.2, \mathrm{CH}$ & \\
7 & $148.1, \mathrm{C}$ & \\
8 & $145.5, \mathrm{C}$ & \\
9 & $104.1, \mathrm{CH}$ & \\
$9 \mathrm{a}$ & $116.3, \mathrm{C}$ & \\
$9 \mathrm{~b}$ & $115.5, \mathrm{C}$ & \\
$1-\mathrm{CH}_{3}$ & $12.3, \mathrm{CH}_{3}$ & $2.56, \mathrm{~s}$ \\
$3-\mathrm{OCH}_{3}$ & $56.2, \mathrm{OCH}_{3}$ & $3.87, \mathrm{~s}$ \\
$7-\mathrm{OCH}_{3}$ & $56.0, \mathrm{OCH}_{3}$ & $3.84, \mathrm{~s}$ \\
$8-\mathrm{OCH}_{3}$ & $56.3, \mathrm{OCH}_{3}$ & $3.86, \mathrm{~s}$ \\
\hline
\end{tabular}

Quinadoline $\mathrm{D}(4)$ was obtained as a yellow powder. Its molecular formula was determined as $\mathrm{C}_{27} \mathrm{H}_{25} \mathrm{~N}_{5} \mathrm{O}_{4}$ according to the HRESIMS peak at $\mathrm{m} / \mathrm{z} 484.1966[\mathrm{M}+\mathrm{H}]^{+}$(Figure S30). The IR and UV spectra of 4 were very similar to those of quinadoline A (5) [11]. This suggested that compound 4 was a pyrazinoquinazoline derivative. Comparing its MS and NMR data with those in compound 5 (Table 3, Figures S23 and S24), compound 4 has 2 amu less than 5 in the MS spectrum, and it showed vicinal-coupling methylene groups (31- $\mathrm{CH}_{2}$ and $\left.32-\mathrm{CH}_{2}\right)$ in 4 , instead of two methyl groups in 5 . The above cyclopropane fragment was further observed in the COSY spectrum (Figure 2), and verified by the key HMBC correlations from both $\mathrm{H}-31$ and $\mathrm{H}-32$ to $\mathrm{C}-22$ and $\mathrm{C}-23$. The NOE correlation observed between H-20 and H-15a, and absence of an NOE correlation between H-20 and OH-19 (Figure S29) revealed that $\mathrm{H}-20$ and $\mathrm{OH}-19$ were cofacial. The ECD spectrum of compound 4 was matched to 5 (Figure 3). It was hypothesized that compound 4 has the same absolute configuration as that of 5. ECD calculations were further employed to determine the absolute configuration. The predicted ECD spectrum was obtained by the TDDFT [mPW1PW91/6-311G(d)] method, and was subsequently compared with the experimental data (Figure S32). As shown in Figure 3, the calculated ECD spectrum was in good accordance with the experimental curve, confirming the absolute configuration of compound 4 as 14R, 19S, 20R (Figure 3). 


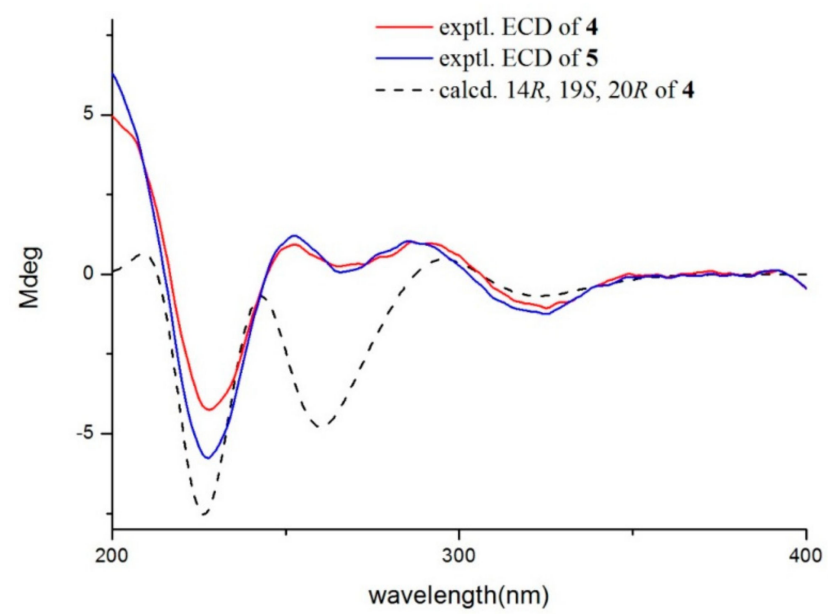

Figure 3. Comparison of measured and calculated ECD spectrums of 4 and 5 (Calcd. ECD curves with a bathochromic shift for $10 \mathrm{~nm}$ ).

Table 3. ${ }^{1} \mathrm{H}$ and ${ }^{13} \mathrm{C}$ NMR Data for $4\left({ }^{1} \mathrm{H} 500 \mathrm{MHz},{ }^{13} \mathrm{C} 125 \mathrm{MHz}, \mathrm{TMS}, \delta \mathrm{ppm}\right)$.

\begin{tabular}{|c|c|c|}
\hline \multirow{2}{*}{ Position } & \multicolumn{2}{|r|}{$4^{a}$} \\
\hline & $\delta_{\mathrm{C}}$, Type & $\delta_{\mathrm{H}}(J$ in $\mathrm{Hz})$ \\
\hline 1 & $166.5, \mathrm{C}$ & \\
\hline 3 & $121.5, \mathrm{C}$ & \\
\hline 4 & $146.8, \mathrm{C}$ & \\
\hline 6 & $146.8, \mathrm{C}$ & \\
\hline 7 & 127.1, CH & $7.66, \mathrm{~d}(8.2)$ \\
\hline 8 & $134.6, \mathrm{CH}$ & $7.85, \mathrm{t}(7.7)$ \\
\hline 9 & $126.9, \mathrm{CH}$ & $7.55, \mathrm{t}(7.4)$ \\
\hline 10 & $126.3, \mathrm{CH}$ & $8.16, \mathrm{~d}(8.3)$ \\
\hline 11 & $119.6, \mathrm{C}$ & \\
\hline 12 & $159.9, \mathrm{C}$ & \\
\hline 14 & $52.5, \mathrm{CH}$ & $5.43, \mathrm{t}(6.5)$ \\
\hline 15 & $37.5, \mathrm{CH}_{2}$ & $\begin{array}{l}\text { 15a: } 2.48, \mathrm{dd}(8.2,14.8) \\
15 \mathrm{~b}: 2.57, \mathrm{dd}(5.4,14.8)\end{array}$ \\
\hline 16 & $130.8, \mathrm{C}$ & \\
\hline 17 & $21.5, \mathrm{CH}_{3}$ & $2.31, \mathrm{~s}$ \\
\hline 18 & $21.1, \mathrm{CH}_{3}$ & $1.96, \mathrm{~s}$ \\
\hline 19 & $75.1, \mathrm{C}$ & \\
\hline 20 & $80.5, \mathrm{CH}$ & $5.25, \mathrm{~d}(9.5)$ \\
\hline 22 & $46.6, \mathrm{C}$ & \\
\hline 23 & 173.5, C & \\
\hline 25 & $138.3, \mathrm{C}$ & \\
\hline 26 & 124.3, $\mathrm{CH}$ & $7.10, \mathrm{~m}$ \\
\hline 27 & $129.7, \mathrm{CH}$ & $7.33, \mathrm{~m}$ \\
\hline 28 & $114.4, \mathrm{CH}$ & $7.33, \mathrm{~m}$ \\
\hline 29 & $124.6, \mathrm{CH}$ & $7.35, \mathrm{~m}$ \\
\hline 30 & 137.1, C & \\
\hline 31 & $14.3, \mathrm{CH}_{2}$ & $0.84, \mathrm{~m}$ \\
\hline 32 & $10.9, \mathrm{CH}_{2}$ & $1.01, \mathrm{~m} ; 0.93, \mathrm{~m}$ \\
\hline $19-\mathrm{OH}$ & & 5.68, br s \\
\hline 2-NH & & 10.04, br s \\
\hline 21-NH & & $3.57, \mathrm{~d}(9.4)$ \\
\hline
\end{tabular}

${ }^{\text {a }}$ Recorded in DMSO- $d_{6}$. 


\subsection{The Bioactivities of Compounds}

Compounds 1-4 were tested for their cytotoxicity against MCF-7, A549, U87 and PC3 cancer cell lines using the 3-(4,5)-dimethylthiahiazo(-z-y1)-3,5-di-phenytetrazoliumromide (MTT) method [26] (Table 4). Adriamycin was employed as the positive control in the cytotoxicity test. Compound 1 showed cytotoxicity against the MCF-7, U87 and PC 3 cell lines with $\mathrm{IC}_{50}$ values of $12.39 \mu \mathrm{M}, 9.01 \mu \mathrm{M}$ and $14.59 \mu \mathrm{M}$, respectively. Compound 2 also exhibited cytotoxicity against MCF-7, U87 and PC3 cell lines with $\mathrm{IC}_{50}$ values of $25.32 \mu \mathrm{M}, 13.45 \mu \mathrm{M}$ and $19.93 \mu \mathrm{M}$, respectively. Compounds 1-4 were also evaluated for their antibacterial activities against the bacteria Staphylococcus aureus, Bacillus subtilis, Pseudomonas aeruginosa and Escherichia coli, by applying the disk diffusion method, according to the Clinical and Laboratory Standards Institute (CLSI) [27]. Unfortunately, none of these compounds were effective against the tested microorganisms.

Table 4. Cytotoxic activities of compounds 1-4.

\begin{tabular}{ccccc}
\hline \multirow{2}{*}{ Compounds } & \multicolumn{5}{c}{ IC $_{50}$} \\
\cline { 2 - 5 } & MCF-7 & A549 & U87 & PC3 \\
\hline $\mathbf{1}$ & $12.39 \pm 2.43$ & $>40$ & $9.01 \pm 2.36$ & $14.59 \pm 2.75$ \\
$\mathbf{2}$ & $25.32 \pm 3.22$ & $>40$ & $13.45 \pm 3.12$ & $19.93 \pm 3.48$ \\
$\mathbf{3}$ & $>40$ & $>40$ & $>40$ & $>40$ \\
$\mathbf{4}$ & $>40$ & $>40$ & $>40$ & $>40$ \\
Adriamycin & $2.03 \pm 0.42$ & $1.53 \pm 0.37$ & $1.21 \pm 0.50$ & $0.98 \pm 0.23$ \\
\hline
\end{tabular}

All of the compounds were evaluated for their QS inhibitory activity against C. violaceum CV026. C30 was applied as the positive control in the QS inhibitory activity test. Compounds $\mathbf{2}$ and $\mathbf{8}$ displayed weak QS inhibitory activity against $C$. violaceum CV026 both with an MIC value of $20 \mu \mathrm{g} /$ well (Figure S33). Compound 10 was a classical QS inhibitory active compound, penicillic acid. By comparing compounds $\mathbf{1 0}$ and $\mathbf{1 1}$ with structurally related metabolites, it was revealed that alterations to the alkene bond side chain substitutions could significantly influence their QS inhibitory activity. In addition, all of the compounds were tested for their antifungal activities against four agricultural pathogens Colletotrichum musae (ACCC 31244), Colletotrichum coccodes (ACCC 36067), Colletotrichum asianum T0408 and Magnaporthe grisea (ACCC 37631), using the disk diffusion method according to the CLSI $[27,28]$. The results showed that compounds $\mathbf{1 2}-\mathbf{1 5}$ had potent inhibitory activities against $C$. musae (ACCC 31244), and compound 14 also showed inhibitory activity against C. coccodes (ACCC 36067) (Table 5 and Figure S34). The positive control used in the antifungal activity test was cycloheximide.

Table 5. Minimum inhibitory concentrations (MIC) of the compounds 12-15 against fungal pathogens ${ }^{\mathrm{a}}$.

\begin{tabular}{ccccc}
\hline Organism & $\mathbf{1 2}$ & $\mathbf{1 3}$ & $\mathbf{1 4}$ & $\mathbf{1 5}$ \\
\hline Colletotrichum musae (ACCC 31244) & 1 & 0.1 & $<10$ & $>1$ \\
Colletotrichum coccodes (ACCC 36067) & NA & NA & $<10$ & NA \\
\hline
\end{tabular}

a All values are in $\mu \mathrm{g} / \mathrm{scrip}$ and derived from experiments in triplicate; NA: no activity at the concentration of $10 \mu \mathrm{g} / \mathrm{scrip}$; Compound 14 did not have enough mass to get MIC data.

\section{Materials and Methods}

\subsection{General Experimental Procedures}

Optical rotations were measured with a JASCO P-1020 digital polarimeter (JASCO Corporation, Tokyo, Japan). ECD spectra were measured on a JASCO J-715 (JASCO) or Chirascan CD (Applied Photophysics) spectropolarimeter. IR spectra were recorded on a Nicolet iS5 (Thermo Fisher Scientific, USA) in KBr discs. NMR spectra were obtained on a Bruker Advance spectrometer operating at $500\left({ }^{1} \mathrm{H}\right)$ and $125\left({ }^{13} \mathrm{C}\right) \mathrm{MHz}$ using TMS as an internal standard, with chemical shifts recorded as $\delta$ 
values. Mass spectra were obtained on an LTQ-Orbitrap spectrometer equipped with an ESI source. Flash chromatography was performed on a Teledyne ISCO CombiFlash Rf 200 system. The high performance liquid chromatography (HPLC) system (Tianjin Bonna-Agela Technologies Co., Ltd., China) was composed of two HP-Q-P050 high pressure pumps equipped with a HP-Q-UV100S variable UV detector, a ATS-051-H10 automatic sampler, a FL-C100B fraction collector, and a Innoval column $(10 \times 250 \mathrm{~mm}, 10 \mu \mathrm{m})$. The semi-preparative HPLC system (Agilent 1260 Infinity II; Agilent technologies, Germany) was equipped with a 1260 Quat Pump VL, a 1260 Vialsampler, a 1260 MCT, a 1260 DAD $W R$, and an ZORBAX SB-C18 column $(5 \mu \mathrm{m}, 9.4 \times 250 \mathrm{~mm})$. Thin-layer chromatography (TLC) was performed with silica gel $\mathrm{GF}_{254}$ plates (Qingdao Haiyang Chemical Co., Ltd., China). Column chromatography was performed on silica gel (200-300 mesh, Qingdao Haiyang Chemical Co., Ltd., China). Size exclusion chromatography was performed using Sephadex LH-20 (25-100 $\mu$ m; Pharmacia, Uppsala, Sweden).

\subsection{Fungal and Plant Material}

The fungal strain Penicillium sp. L129 was isolated from the rhizosphere-soil of Limonium sinense (Girald) Kuntze collected in Yangkou Beach, Qingdao, China. It was identified according to its morphological characteristics and the analysis of the internal transcribed spacer (ITS) region of $16 \mathrm{~S}$ rDNA (Genbank access No. MK625482). The fungus was deposited at the School of Pharmacy, Qingdao University, China, and was maintained at $-80^{\circ} \mathrm{C}$.

\subsection{Fermentation and Extraction}

For large-scale fermentation, the fresh mycelia of Penicillium sp. L129 were cultured on potato dextrose agar (PDA) medium at $28 \pm 2{ }^{\circ} \mathrm{C}$ for five days. The agar plugs were cut into small pieces under aseptic conditions, and 150 pieces were used to inoculate 50 flasks $(500 \mathrm{~mL})$ each containing $80 \mathrm{~g}$ rice, $120 \mathrm{~mL}$ seawater, and $0.24 \mathrm{~g}$ peptone. The cultures were inoculated at $28 \pm 2{ }^{\circ} \mathrm{C}$ for 40 days. After 40 days of cultivation, the fermented cultures were extracted three times with ethyl acetate (EtOAc). The organic solvent was evaporated under reduced pressure to afford the crude extract (40.7 g).

\subsection{Purification and Identification}

The obtained EtOAc crude extract $(40.7 \mathrm{~g}$ ) based on TLC analysis was fractionated into six fractions (Fr.1 to Fr.6) by column chromatography on silica gel, eluting with a gradient of $\mathrm{CH}_{2} \mathrm{Cl}_{2}-\mathrm{MeOH}$ $(100-50 \%)$. Fr.2 (24.5 g) was fractionated by silica gel column chromatography with a gradient of EtOAc-petroleum ether (3\%-100\%) to give eight subfractions (Fr.2.1 to Fr.2.8). Fr.2.2 (283.0 mg) was purified by HPLC ( $\left.\mathrm{MeOH} / \mathrm{H}_{2} \mathrm{O}, 50 / 50,4 \mathrm{~mL} / \mathrm{min}\right)$ to yield $1\left(2.0 \mathrm{mg}, t_{\mathrm{R}} 14.5 \mathrm{~min}\right), \mathbf{6}\left(7.0 \mathrm{mg}, t_{\mathrm{R}} 8.3 \mathrm{~min}\right)$, and $9\left(1.1 \mathrm{mg}, t_{\mathrm{R}} 22.2 \mathrm{~min}\right)$. Fr.2.3 (1.9 g) was separated through a Sephadex LH-20 chromatograph (MeOH as eluent) to give Fr.2.3.1 and Fr.2.3.2. Fr.2.3.1 (1.4 g) was separated by a CombiFlash Rf 200 purification system (eluting with $\mathrm{MeOH}-\mathrm{H}_{2} \mathrm{O}, 5 \% \mathrm{MeOH}$ for $5 \mathrm{~min}$, a gradient of $5-100 \% \mathrm{MeOH}$ over $20 \mathrm{~min}, 100 \% \mathrm{MeOH}$ for $10 \mathrm{~min}$ ), which obtained four subfractions (Fr.2.3.1.1 to Fr.2.3.1.4), and Fr.2.3.1.4 $(21.8 \mathrm{mg})$ was further purified by semi-preparative $\mathrm{HPLC}\left(\mathrm{MeOH} / \mathrm{H}_{2} \mathrm{O}, 70 / 30,2 \mathrm{~mL} / \mathrm{min}\right)$ to give compounds 3 (1.7 mg, $\left.t_{R} 14.6 \mathrm{~min}\right), 16\left(0.8 \mathrm{mg}, t_{\mathrm{R}} 19.2 \mathrm{~min}\right)$, and $17\left(0.6 \mathrm{mg}, t_{\mathrm{R}} 26.7 \mathrm{~min}\right)$. Fr.2.3.2 $(64.6 \mathrm{mg})$ was applied to Sephadex $\mathrm{LH}-20(\mathrm{MeOH}$ as eluent) to yield four subfractions (Fr.2.3.2.1 to Fr.2.3.2.4), and Fr.2.3.2.2 (12.0 mg) was further purified by semi-preparative $\mathrm{HPLC}\left(\mathrm{MeOH} / \mathrm{H}_{2} \mathrm{O}\right.$, 55/45, $2 \mathrm{~mL} / \mathrm{min}$ ) to give compound $2\left(4.8 \mathrm{mg}\right.$, $t_{\mathrm{R}} 9.3 \mathrm{~min}$ ), while Fr.2.3.2.3 (25.6 mg) was further purified by semi-preparative HPLC $\left(\mathrm{MeOH} / \mathrm{H}_{2} \mathrm{O}, 50 / 50,2 \mathrm{~mL} / \mathrm{min}\right)$ to give compound $7(11.5 \mathrm{mg}$, $\left.t_{\mathrm{R}} 8.0 \mathrm{~min}\right)$. Part of Fr.2.5 (250.0 mg) was separated through a Sephadex LH-20 chromatograph $(\mathrm{MeOH}$ as eluent) to give Fr.2.5.1 to Fr.2.5.2, and Fr.2.5.1 (200.0 mg) was purified through HPLC $\left(\mathrm{MeOH} / \mathrm{H}_{2} \mathrm{O}\right.$, 40/60, $4 \mathrm{~mL} / \mathrm{min}$ ) to obtain compounds $\mathbf{1 0}\left(150.0 \mathrm{mg}, t_{\mathrm{R}} 7.5 \mathrm{~min}\right)$ and $\mathbf{1 1}\left(6.0 \mathrm{mg}, t_{\mathrm{R}} 10.5 \mathrm{~min}\right)$. Fr.2.7 (128.2 mg) was purified through HPLC $\left(\mathrm{MeOH} / \mathrm{H}_{2} \mathrm{O}, 55 / 45,4 \mathrm{~mL} / \mathrm{min}\right)$ to provide compounds 12 (4.3 $\left.\mathrm{mg}, t_{\mathrm{R}} 14.7 \mathrm{~min}\right), \mathbf{1 3}\left(3.7 \mathrm{mg}, t_{\mathrm{R}} 22.9 \mathrm{~min}\right), \mathbf{1 4}\left(0.6 \mathrm{mg}, t_{\mathrm{R}} 26.0 \mathrm{~min}\right)$, and $\mathbf{1 5}\left(0.9 \mathrm{mg}, t_{\mathrm{R}} 20.8 \mathrm{~min}\right)$. Fr.2.8 
( $0.5 \mathrm{~g})$ was subjected to semi-preparative HPLC $\left(\mathrm{MeOH} / \mathrm{H}_{2} \mathrm{O}, 65 / 35,2 \mathrm{~mL} / \mathrm{min}\right)$ to yield compounds 4 $\left(1.7 \mathrm{mg}, t_{\mathrm{R}} 17.6 \mathrm{~min}\right)$ and $\mathbf{5}\left(2.2 \mathrm{mg}, t_{\mathrm{R}} 20.5 \mathrm{~min}\right)$. Then, Fr.3 (3.7 g) was fractionated by a CombiFlash Rf 200 purification system (eluting with $\mathrm{MeOH}-\mathrm{H}_{2} \mathrm{O}, 5 \% \mathrm{MeOH}$ for $5 \mathrm{~min}$, a gradient of $5-100 \% \mathrm{MeOH}$ over $20 \mathrm{~min}, 100 \% \mathrm{MeOH}$ for $10 \mathrm{~min}$ ) to give four subfractions (Fr.3.1 to Fr.3.4), and Fr.3.4 (700 mg) was subjected to semi-preparative HPLC $\left(\mathrm{MeOH} / \mathrm{H}_{2} \mathrm{O}, 60 / 40,2 \mathrm{~mL} / \mathrm{min}\right)$ to yield compound $8(9.2 \mathrm{mg}$, $\left.t_{\mathrm{R}} 18.7 \mathrm{~min}\right)$.

Compound 1. Red oil; UV ( $\left.\mathrm{CH}_{3} \mathrm{OH}\right) \lambda_{\max }(\log \varepsilon) 200,274,352 \mathrm{~nm}$; IR (KBr) $v_{\max } 3431,2927,1682$, $1617,1229,1040 \mathrm{~cm}^{-1}$; HRESIMS $\mathrm{m} / \mathrm{z} 319.1171\left([\mathrm{M}+\mathrm{H}]{ }^{+}\right.$, calcd. for $\left.\mathrm{C}_{17} \mathrm{H}_{18} \mathrm{O}_{6} 319.1176\right) ;{ }^{13} \mathrm{C} \mathrm{NMR}$ and ${ }^{1} \mathrm{H}$ NMR (Table 1).

Compound 2. Red oil; UV $\left(\mathrm{CH}_{3} \mathrm{OH}\right) \lambda_{\max }(\log \varepsilon) 216,270,380 \mathrm{~nm}$; IR (KBr) $v_{\max } 3431,2921,2850$, $1621,1463,1377,1231,720 \mathrm{~cm}^{-1}$; HRESIMS $\mathrm{m} / z 273.0767$ ([M - H] $]^{-}$, calcd. for $\mathrm{C}_{15} \mathrm{H}_{13} \mathrm{O}_{5}$ 273.0768); ${ }^{13} \mathrm{C}$ NMR and ${ }^{1} \mathrm{H}$ NMR (Table 1$)$.

Compound 3. Brown powder; UV $\left(\mathrm{CH}_{3} \mathrm{OH}\right) \lambda_{\max }(\log \varepsilon) 226,252,316 \mathrm{~nm} ; \mathrm{IR}(\mathrm{KBr}) v_{\max } 3438$, 2922, 2852, 1632, 1463, 1384, 1261, 1119, $585 \mathrm{~cm}^{-1}$; HRESIMS $\mathrm{m} / \mathrm{z} 289.1079\left([\mathrm{M}+\mathrm{H}]^{+}\right.$, calcd. for $\left.\mathrm{C}_{16} \mathrm{H}_{17} \mathrm{O}_{5} 289.1071\right) ;{ }^{13} \mathrm{C}$ NMR and ${ }^{1} \mathrm{H}$ NMR (Table 2$)$.

Compound 4. Yellow powder; UV $\left(\mathrm{CH}_{3} \mathrm{OH}\right) \lambda_{\max }(\log \varepsilon) 210,230,292 \mathrm{~nm} ; \mathrm{IR}(\mathrm{KBr}) v_{\max } 3432$, 2923, 2853, 1628, 1464, 1378, $1128 \mathrm{~cm}^{-1}$; $[\alpha]_{D}^{25}$-6. (c 0.1, MeOH); HRESIMS m/z $484.1966\left([\mathrm{M}+\mathrm{H}]^{+}\right.$, calcd. for $\left.\mathrm{C}_{27} \mathrm{H}_{26} \mathrm{~N}_{5} \mathrm{O}_{4} 484.1979\right) ;{ }^{13} \mathrm{C}$ NMR and ${ }^{1} \mathrm{H}$ NMR (Table 3).

\subsection{QS inhibitory Activity Essay}

The in vitro QS inhibitory activity assay was carried out against the C. violaceum CV026. The strain C. violaceum CV026 was inoculated in a $20 \mathrm{~mL}$ LB broth medium $(\mathrm{NaCl} 10 \mathrm{~g} / \mathrm{L}$, Tryptone $10 \mathrm{~g} / \mathrm{L}$, Yeast Extract $5 \mathrm{~g} / \mathrm{L})$ at $37^{\circ} \mathrm{C}$ on a rotary shaker $(220 \mathrm{rpm})$ overnight. The culture $(0.2 \mathrm{~mL})$ was further mixed with $15 \mathrm{~mL}$ of warm molten LB agar $\left(\sim 40^{\circ} \mathrm{C}\right)$ containing kanamycin (Sigma, $0.72 \mathrm{mg}$ ) and $\mathrm{N}$-hexanoyl-L-homoserine-lactone (C6-HSL) (Sigma, $1.5 \mu \mathrm{g}$ ). The agar was poured into a Petri dish and then punched with a sterile cork borer $(\Phi 5 \mathrm{~mm})$. The methanol solution $(10 \mu \mathrm{L})$ of tested compounds at the concentration of $40 \mu \mathrm{g} /$ well were pipetted into each well. Furanone C30 at the concentration of $10 \mu \mathrm{g} /$ well was employed as the positive control while methanol was used as the negative control. The plates were then incubated overnight at $37^{\circ} \mathrm{C}$.

\subsection{Cytotoxic Activity Essay}

The MCF-7 and PC3 cell lines were obtained from the American Type Culture Collection (Manassas, VA) [29]. The A549 cell line was purchased from the Shanghai Institute for Biological Sciences, China Academy of Sciences (China) [30]. The U87 cell line was obtained from Dr. Bing Yan (Shan Dong University) [31].

\section{Conclusions}

We identified 17 compounds from the fermentation of Penicillium sp. L129, including two new dimeric 1,4-benzoquinone, peniquinone $A(\mathbf{1})$ and peniquinone $B(2)$, a new dibenzofuran derivative penizofuran $A(3)$ and a new pyrazinoquinazoline derivative quinadoline $D(4)$. Compounds 1-4 were screened for their cytotoxic activity against MCF-7, A549, U87 and PC3 cancer cell lines, and antibacterial activities against Gram-positive bacteria S. aureus and B. subtilis and Gram-negative bacteria P. aeruginosa and E. coli. All the compounds were tested for their QS inhibitory activity against $C$. violaceum $\mathrm{CV} 026$ and antifungal activities against C. musae (ACCC 31244), C. coccodes (ACCC 36067), M. grisea (ACCC 37631) and C. asianum T0408. Compound 1 showed cytotoxicity against the MCF-7, U87 and PC3 cell lines with $\mathrm{IC}_{50}$ values of $12.39 \mu \mathrm{M}, 9.01 \mu \mathrm{M}$ and $14.59 \mu \mathrm{M}$, respectively, while compound 2 exhibited cytotoxicity against MCF-7, U87 and PC3 cell lines with IC 50 values of $25.32 \mu \mathrm{M}, 13.45 \mu \mathrm{M}$ and $19.93 \mu \mathrm{M}$, respectively. The known compounds $\mathbf{1 3}$ and $\mathbf{1 4}$ had potent antifungal activities against C. musae (ACCC 31244), both with an MIC values of $0.1 \mu \mathrm{g} / \mathrm{scrip}$, and compound 14 also showed antifungal activity against $C$. coccodes (ACCC 36067) with an MIC value of $0.1 \mu \mathrm{g} / \mathrm{scrip}$. Compounds 
2 and 8 displayed weak QS inhibitory activities against $C$. violaceum $C$ V026 both with an MIC value of $20 \mu \mathrm{g} /$ well. Compound 10 was penicillic acid, showing obvious QS inhibitory activity. The results suggested that the marine-derived fungi are an important source of new bioactive substances.

Supplementary Materials: The following are available online at http://www.mdpi.com/1660-3397/17/7/383/s1, Figures S1-S36: HRESIMS, IR and NMR spectra of the new compounds 1-4, the quantum calculation details are supplied, the QS inhibitory and antifungal activities, the 16S rDNA gene sequence of Penicillium sp. L129, and the HPLC data of compounds 1-4 are supplied.

Author Contributions: H.-M.Z. contributed to compounds purification, structural elucidation, bioassay and the preparation of the paper. C.-X.J. isolated and identified the strain. G.L. was responsible for the analysis of ECD calculations. Y.S contributed to the cytotoxicity test. Y.P. and Y.-X.L. were responsible for the strain preservation and fermentation. H.-X.L. and X.-P.P. designed the work and revised the paper.

Funding: This work was supported financially by the National Natural Science Foundation of China [grant number 40218030034], China Postdoctoral Science Foundation [grant number 2019M652309] and the Natural Science Foundation of Shandong Province [grant number ZR2018BC001].

Acknowledgments: We gratefully acknowledge Dr. Wen-Xuan Wang (School of pharmaceutical Science, South-Central University of Nationalities) for the quantum chemistry calculations and valuable discussions.

Conflicts of Interest: The authors declare no conflict of interest.

\section{References}

1. Carroll, A.R.; Copp, B.R.; Davis, R.A.; Keyzers, R.A.; Prinsep, M.R. Marine natural products. Nat. Prod. Rep. 2019, 36, 122-173. [CrossRef] [PubMed]

2. Liu, S.; Su, M.; Song, S.J.; Jung, J.H. Marine-derived Penicillium species as producers of cytotoxic metabolites. Mar. Drugs 2017, 15, 329. [CrossRef] [PubMed]

3. Meng, L.H.; Wang, C.Y.; Mandi, A.; Li, X.M.; Hu, X.Y.; Kassack, M.U.; Kurtan, T.; Wang, B.G. Three diketopiperazine alkaloids with spirocyclic skeletons and one bisthiodiketopiperazine derivative from the mangrove-derived endophytic fungus Penicillium brocae MA-231. Org. Lett. 2016, 18, 5304-5307. [CrossRef]

4. Liao, L.; Bae, S.Y.; Won, T.H.; You, M.; Kim, S.H.; Oh, D.C.; Lee, S.K.; Oh, K.B.; Shin, J. Asperphenins A and B, lipopeptidyl benzophenones from a marine-derived Aspergillus sp. Fungus. Org. Lett. 2017, 19, $2066-2069$. [CrossRef] [PubMed]

5. Chen, S.; Wang, J.; Lin, X.; Zhao, B.; Wei, X.; Li, G.; Kaliaperumal, K.; Liao, S.; Yang, B.; Zhou, X.; et al. Chrysamides A-C, three dimeric nitrophenyl trans-Epoxyamides produced by the deep-sea-derived fungus Penicillium chrysogenum SCSIO41001. Org. Lett. 2016, 18, 3650-3653. [CrossRef] [PubMed]

6. Wang, W.; Liao, Y.; Zhang, B.; Gao, M.; Ke, W.; Li, F.; Shao, Z. Citrinin monomer and dimer derivatives with antibacterial and cytotoxic activities isolated from the deep sea-derived fungus Penicillium citrinum NLG-S01-P1. Mar. Drugs 2019, 17, 46. [CrossRef]

7. Lu, Z.Y.; Lin, Z.J.; Wang, W.L.; Du, L.; Zhu, T.J.; Fang, Y.C.; Gu, Q.Q.; Zhu, W.M. Citrinin dimers from the halotolerant fungus Penicillium citrinum B-57. J. Nat. Prod. 2008, 71, 543-546. [CrossRef]

8. Leong, S.L.; Schnurer, J.; Broberg, A.; Verrucine, F. A quinazoline from Penicillium verrucosum. J. Nat. Prod. 2008, 71, 1455-1457. [CrossRef]

9. Michael, J.P. Quinoline, quinazoline and acridone alkaloids. Nat. Prod. Rep. 2008, 25, 166-187. [CrossRef]

10. Hu, X.Y.; Meng, L.H.; Li, X.; Yang, S.Q.; Li, X.M.; Wang, B.G. Three new indole diterpenoids from the sea-anemone-derived fungus Penicillium sp. AS-79. Mar. Drugs 2017, 15, 137. [CrossRef]

11. Huang, L.H.; Xu, M.Y.; Li, H.J.; Li, J.Q.; Chen, Y.X.; Ma, W.Z.; Li, Y.P.; Xu, J.; Yang, D.P.; Lan, W.J. Amino acid-directed strategy for inducing the marine-derived fungus Scedosporium apiospermum F41-1 to maximize alkaloid diversity. Org. Lett. 2017, 19, 4888-4891. [CrossRef] [PubMed]

12. Tadross, P.M.; Gilmore, C.D.; Bugga, P.; Virgil, S.C.; Stoltz, B.M. Regioselective reactions of highly substituted arynes. Org. Lett. 2010, 12, 1224-1227. [CrossRef] [PubMed]

13. Rojas, I.S.; Lotina-Hennsen, B.; Mata, R. Effect of lichen metabolites on thylakoid electron transport and photophosphorylation in isolated spinach chloroplasts. J. Nat. Prod. 2000, 63, 1396-1399. [CrossRef] [PubMed] 
14. Belofsky, G.N.; Gloer, K.B.; Gloer, J.B.; Wicklow, D.T.; Dowd, P.F. New p-terphenyl and polyketide metabolites from the sclerotia of Penicillium raistrickii. J. Nat. Prod. 1998, 61, 1115-1119. [CrossRef] [PubMed]

15. Feng, C.C.; Chen, G.D.; Zhao, Y.Q.; Xin, S.C.; Li, S.; Tang, J.S.; Li, X.X.; Hu, D.; Liu, X.Z.; Gao, H. New isocoumarins from a cold-adapted fungal strain Mucor sp. and their developmental toxicity to zebrafish embryos. Chem. Biodivers. 2014, 11, 1099-1108. [CrossRef] [PubMed]

16. Kimura, Y.; Nakahara, S.; Fujioka, S. Aspyrone, a nematicidal compound isolated from the fungus, Aspergillus melleus. Biosci. Biotechnol. Biochem. 1996, 60, 1375-1376. [CrossRef]

17. Shang, Z.; Li, X.M.; Li, C.S.; Wang, B.G. Diverse secondary metabolites produced by marine-derived fungus Nigrospora sp. MA75 on various culture media. Chem. Biodivers. 2012, 9, 1338-1348. [CrossRef]

18. Zhao, J.H.; Zhang, Y.L.; Wang, L.W.; Wang, J.Y.; Zhang, C.L. Bioactive secondary metabolites from Nigrospora sp. LLGLM003, an endophytic fungus of the medicinal plant Moringa oleifera lam. World J. Microb. Biot. 2012, 28, 2107-2112. [CrossRef]

19. Levine, S.G.; Hicks, R.E.; Gottlieb, H.E.; Wenkert, E. Carbon-13 nuclear magnetic resonance spectroscopy of naturally occurring substances. XXX. Griseofulvin. J. Org. Chem. 1975, 40, 2540-2542. [CrossRef]

20. Wubshet, S.G.; Nyberg, N.T.; Tejesvi, M.V.; Pirttila, A.M.; Kajula, M.; Mattila, S.; Staerk, D. Targeting high-performance liquid chromatography-high-resolution mass spectrometry-solid-phase extraction-nuclear magnetic resonance analysis with high-resolution radical scavenging profiles-bioactive secondary metabolites from the endophytic fungus Penicillium namyslowskii. J. Chromatogr. A. 2013, 1302, 34-39.

21. Lin, L.Z.; West, D.P.; Cordell, G.A. NMR assignments of cis- and trans-capsaicin. Nat. Prod. Lett. 2006, 3, 5-8. [CrossRef]

22. Gomez-Calvario, V.; Garduno-Ramirez, M.L.; Leon-Rivera, I.; Rios, M.Y. ${ }^{1} \mathrm{H}$ and ${ }^{13} \mathrm{C}$ NMR data on natural and synthetic capsaicinoids. Magn. Reson. Chem. 2016, 54, 268-290. [PubMed]

23. Liu, H.; Zhao, F.; Yang, R.; Wang, M.; Zheng, M.; Zhao, Y.; Zhang, X.; Qiu, F.; Wang, H. Dimeric 1,4-benzoquinone derivatives and a resorcinol derivative from Ardisia gigantifolia. Phytochemistry 2009, 70, 773-778. [CrossRef] [PubMed]

24. Fukuyama, Y.; Kiriyama, Y.; Okino, J.; Kodama, M. Belamcandaquinones A and B, novel dimeric 1,4-benzoquinone derivatives possessing cyclooxygenase inhibitory activity. Tetrahedron Lett. 1993, 34, 7633-7636. [CrossRef]

25. Ko, R.K.; Lee, S.; Hyun, C.G.; Lee, N.H. New dibenzofurans from the branches of Distylium racemosum Sieb. et Zucc. Bull. Korean Chem. Soc. 2009, 30, 1376-1378.

26. Xu, K.; Gao, Y.; Li, Y.L.; Xie, F.; Zhao, Z.T.; Lou, H.X. Cytotoxic $p$-terphenyls from the endolichenic fungus Floricola striata. J. Nat. Prod. 2018, 81, 2041-2049. [CrossRef]

27. Michael, A.; Pfaller, M.D.; Ronald, N.; Jones, M.D. Performance accuracy of antibacterial and antifungal susceptibility test methods: Report from the College of American Pathologists (CAP) microbiology surveys program (2001-2003). Arch. Pathol. Lab. Med. 2006, 130, 767-778.

28. Li, G.; Kusari, S.; Lamshoft, M.; Schuffler, A.; Laatsch, H.; Spiteller, M. Antibacterial secondary metabolites from an endophytic fungus, Eupenicillium sp. LG41. J. Nat. Prod. 2014, 77, 2335-2341. [CrossRef]

29. Zheng, H.; Dong, Y.; Li, L.; Sun, B.; Liu, L.; Yuan, H.; Lou, H. Novel benzo[a]quinolizidine analogs induce cancer cell death through paraptosis and apoptosis. J. Med. Chem. 2016, 59, 5063-5076. [CrossRef]

30. Sun, B.; Liu, J.; Gao, Y.; Zheng, H.B.; Li, L.; Hu, Q.W.; Yuan, H.Q.; Lou, H.X. Design, synthesis and biological evaluation of nitrogen-containing macrocyclic bisbibenzyl derivatives as potent anticancer agents by targeting the lysosome. Eur. J. Med. Chem. 2017, 136, 603-618. [CrossRef]

31. Zhu, F.H.; Liu, Y.Q.; Lou, H.X. Bisbibenzyl-induced autophagy delays cell death in PC-3 cells. J. Shandong Univ. Health Sci. 2013, 51, 11-17.

(C) 2019 by the authors. Licensee MDPI, Basel, Switzerland. This article is an open access article distributed under the terms and conditions of the Creative Commons Attribution (CC BY) license (http://creativecommons.org/licenses/by/4.0/). 